\title{
Commentary Choice of vasopressor in septic shock: does it matter?
} Gourang P Patel and Robert A Balk

\author{
Rush Medical College, Rush University Medical Center, 1753 West Congress Parkway, Chicago, Illinois 60612, USA
}

Corresponding author: Robert A Balk, rbalk@rush.edu

Published: 6 November 2007

This article is online at http://ccforum.com/content/11/6/174

(c) 2007 BioMed Central Ltd
Critical Care 2007, 11:174 (doi:10.1186/cc6159)

In an attempt to determine the optimum vasopressor to use in the management of patients with septic shock, Annane and coworkers conducted a multicenter, prospective, randomized, double-blind, controlled clinical trial evaluating epinephrine versus norepinephrine (with dobutamine, if indicated) in the management of a well-defined adult population with septic shock [1]. The trial involved patients from 19 intensive care units throughout France and was funded by the French Ministry of Health. The study enrolled adults with well-defined septic shock and evidence of organ dysfunction and/or hypoperfusion. The primary outcome parameter was 28 day all-cause mortality. Despite finding a significantly higher arterial lactate level and lower $\mathrm{pH}$ during the first four days of therapy in the epinephrine treated patients, there was not a significant difference in $\mathbf{2 8}$ day all-cause mortality or other important outcome parameters. Specifically, there was no significant difference in discharge from the intensive care unit (ICU) or hospital, hemodynamic parameters, vasopressor withdrawal or organ dysfunction between the two treatment strategies. Importantly, there was also no difference in adverse events, such as arrhythmias or cardiac, neurologic, or ischemic events [1].

As we consider these intriguing results from the study by Annane and coworkers we are impressed by the intricacies of study design and acknowledge their use of an expanded definition for early septic shock in the inclusion and exclusion criteria for study enrollment. The study was multi-centered, randomized, with a double-blind treatment algorithm. The study participants were reasonably well randomized at the start. The majority of infections were community acquired with the lung as the predominant site of infection. Given the predominance of dopamine use in North America and Europe, we were surprised investigators chose to compare epinephrine and norepinephrine [4-6]. A trial design comparing norepinephrine to dopamine, epinephrine, and possibly vasopressin or phenylephrine would have had more

$\mathrm{ICU}=$ intensive care unit; SCCM $=$ Society of Critical Care Medicine. 
clinical relevance for physicians in North America and Europe [4-6]. The use of epinephrine as an initial vasopressor for the management of septic shock would represent a significant paradigm shift for North America and a majority of Europe $[5,6]$.

In regard to the study results, it is remarkable that the 28 day all-cause mortality rate was $40 \%$ in the epinephrine and $34 \%$ in the norepinephrine patients [1]. This impressive mortality rate is lower than typical reports of $40-70 \%$ for septic shock patients and raises questions regarding the reason for the improvement in 28 day all-cause mortality rate [2]. This observation is even more curious in light of the increased arterial lactate and lower $\mathrm{pH}$ in the epinephrine group over the first few days of management. Even though there was recovery of this metabolic derangement by the fourth study day, there did not appear to be any adverse sequelae. The finding that epinephrine can produce exaggerated aerobic glycolysis within muscles, decrease splanchnic and hepatic blood flow, and may increase oxygen consumption, despite an increase in oxygen delivery to the tissues likely explains the increased arterial lactate and reduced $\mathrm{pH}[4,7,8]$. Lactate has been an important surrogate marker for assessing tissue hypoperfusion [9]. Its measurement and prognostic implications have resulted in its incorporation into sepsis bundles which have been widely adopted to guide initial sepsis management $[10,11]$. Rivers and colleagues also reported a distinct correlation between lactate clearance and outcome in septic shock $[9,12]$. Increased lactate formation and delayed clearance of lactate have been associated with increased mortality rates in septic shock patients [9]. However, these results demonstrate a survival benefit irregardless of the early increases in lactate formation and presumed decrease in clearance. The explanation for the positive survival benefits could be related to the potential impact of the high prevalence of steroid use (approximately $80 \%$ of all patients) in this study. This percent of patients managed with corticosteroid replacement therapy is higher that the typical sepsis trial and represents yet another controversial area of sepsis management [5]. Finally, it is noteworthy that adverse events reported during this trial were similar. The authors also evaluated the patients for significant ischemic events involving the cardiac, neurologic, or peripheral circulation and again there were no significant differences between the two groups, supporting the safety of epinephrine in this study population.

We applaud the efforts of the French investigators to determine if there is a preferred vasopressor to use in septic shock. The current study was particularly well-done, but unfortunately, did not answer the question and raised additional questions for the practicing intensivists. The excellent survival results of this current trial (approximately $60 \%)$ for both epinephrine and norepinephrine treated patients raises the question of whether the excellent outcome was reflective of the vasopressor strategy, increased corticosteroid use, or another variable. The epinephrine outcomes were even more impressive in light of the initial increase in arterial lactate and decrease in $\mathrm{pH}$ observed in these patients compared to the norepinephrine treatment. To help answer these questions and determine if there is a "best vasopressor" we need another large, multicenter, prospective, randomized, controlled trial to compare norepinephrine, dopamine, and epinephrine. Until this data becomes available, it appears that there is no clear "best vasopressor" to use in the management of adults with septic shock.

\section{Competing interests}

The authors declare that they have no competing interests.

\section{References}

1. Annane D, Vignon $P$, Renault A, Bollaert EP, Charpentier C Martin C, Troche G, Ricard JD, Nitenberg GN, Papazian L, Azoulay E, Bellissant E, for the CATS Study Group: Norepinephrine plus dobutamine versus epinephrine alone for the management of septic shock: A randomized trial. Lancet 2007, 370:676-684.

2. Russel JA: Management of sepsis. N Engl J Med 2006, 355: 1699-1713.

3. Dellinger RP, Carlet JM, Masur $\mathrm{H}$, Gerlach $\mathrm{H}$, Calandra T, Cohen J, Gea-Banacloche J, Keh D, Marshall JC, Parker MM, et al.: Surviving Sepsis Campaign Guidelines for the management of patients with sepsis and septic shock. Crit Care Med 2004, 32:858-873

4. Hollenberg SM, Ahrens TS, Annane D, et al.: Practice parameters for hemodynamic support of sepsis in adult patients: 2004 update. Crit Care Med 2004, 32:1928-1948

5. Levy B, Dusang B, Annane D, Annane D, Gibot S, Bollaert PE, and the College Interregional Des Reanimateurs du Nord-Est: Cardiovascular response to dopamine and early prediction of outcome in septic shock: A prospective multiple-center study. Crit Care Med 2005, 33:2172-2177.

6. Sakr Y, Reinhart K, Vincent JL, Spring CL, Moreno R, Ranieri M, De Backer D, Payen D: Does dopamine administration in shock influence outcome? Results of the Sepsis Occurrence in Acutely III Patients (SOAP) Study. Crit Care Med 2006, 34:589-597.

7. Levy B, Bollaert PE, Charpentier C, Nace L, Audibert G, Bauer P, Nabet $P$, Larcan $A$ : Comparison of norepinephrine and dobutamine to epinephrine for hemodynamics, lactate metabolism, and gastric tonometric variables in septic shock: a prospective, randomized study. Intes Care Med 1997, 23:282-287.

8. Seguin P, Bellissant E, Le Tulzo Y, Laviolle B, Lessard Y, Thomas $\mathrm{R}$, Malledant $\mathrm{Y}$ : Effects of epinephrine compared with the combination of dobutamine and norepinephrine on gastric perfusion in septic shock. Clin Pharm Ther 2002, 71:381-388.

9. Rivers E, Nguyen B, Havstad S, Ressler J, Muzzin A, Knoblich B, Peterson E, Tomlanovich M, for the Early Goal-Directed Therapy Collaborative Group: Early-goal directed therapy in the treatment of severe sepsis and septic shock. N Engl J Med 2001, 345:1368-1377.

10. Levy MM, Pronovost PJ, Dellinger RP, Townsend S, Resar RK, Clemmer TP, Ramsay G: Sepsis change bundles: Converting guidelines into meaningful change in behavior and clinical outcome. Crit Care Med 2004, 32:S595-S597.

11. Kortgen A, Niederprum $P$, Bauer M: Implementation of an evidenced-based "standard operating procedure" and outcome in septic shock Crit Care Med 2006 34:943-949.

12. Nguyen HB, Rivers EP, Knobloch BP, Jacobsen G, Muzzin A Ressler JA, Tomlanovich MC: Early lactate clearance is associated with improved outcome in severe sepsis and septic shock. Crit Care Med 2004, 32:1637-1642. 